Journal of Agricultural Sciences
(Tarim Bilimieri Dergisi)

\title{
Effect of Aqueous Methanolic Extract of Pomegranate Peel (Punica granatum) and Veratrum (Veratrum album) on Oxidative Status, Immunity and Digestive Enzyme Activity in Rainbow Trout (Oncorhynchus mykiss)
}

\author{
Adem Yavuz SÖNMEZ ${ }^{*} \mathbb{D}$, Soner BíLENa ${ }^{\mathbb{D}}$, Keriman YÜRÜTEN ÖZDEMİR ${ }^{a} \mathbb{D}$, Kerem ALAGÖZ $^{b} \mathbb{D}$, \\ Halil ÖZÇELİK ${ }^{b}$ (D)

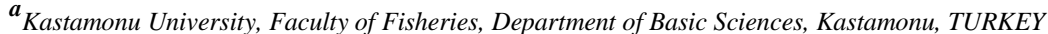

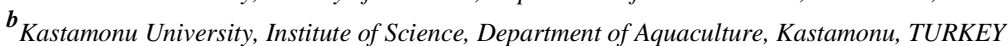

ARTICLE INFO

Research Article

Corresponding Author: Adem Yavuz SÖNMEZ, E-mail: aysonmez@kastamonu.edu.tr

Received: 30 January 2021 / Revised: 03 April 2021 / Accepted: 03 April 2021 / Online: 25 March 2022

\section{ABSTRACT}

Aqueous methanolic extracts of pomegranate peel (Punica granatum) and veratrum (Veratrum album) were evaluated for their effects of supplementation in fish diets on oxidative status, digestive enzymes and immunity of rainbow trout fingerlings (Oncorhynchus mykiss). Three different concentrations of pomegranate 250 (P250), 500 (P500) and 1000 (P1000) $\mathrm{mg} \mathrm{kg}^{-1}$ and veratrum 250 (V250), 500 (V500) and 1000 (V1000) $\mathrm{mg} \mathrm{kg}^{-1}$ were added to the diet and the fish were fed these diets for 60 days over a control diet without any supplementation ( $\mathrm{P} 0$ and $\mathrm{V} 0$, respectively). Immune responses and oxidative status of fish were evaluated every 20 days. Digestive enzyme activity and growth performances were determined at the end of study. We observed that the respiratory burst activity significantly increased $(\mathrm{P}<0.05)$ at the end of the study compared to control except in the V500 fish group. Lysozyme was increased on the $20^{\text {th }}$ and $40^{\text {th }}$ day of the study in all experimental groups compared to the control group $(\mathrm{P}<0.05)$. Myeloperoxidase activity was observed to increase on the $40^{\text {th }}$ day in veratrum treated groups and significantly decreased $(\mathrm{P}<0.05)$ on the $60^{\text {th }}$ day in all groups compared to the control. Haematological responses showed a declining trend in all the groups supplemented with veratrum extract. SOD activity increased in pomegranate groups while no differences were observed on catalase activity. G6PDH activity was observed to decline in the veratrum groups, however, GPx activity significantly increased $(\mathrm{P}<0.05)$ in V500 and V100 groups. Lipid peroxidation was determined at the lowest level on the 20th and 40th days of the study in P1000 and V250 fish groups. The study indicated a positive impact of pomegranate peel extract on the immunity of rainbow trout at moderate doses of supplementation.

Keywords: Immune response, Antioxidant activity, Digestive enzyme, Growth performance, Rainbow trout, Punica granatum, Veratrum album

(C) Ankara University, Faculty of Agriculture

\section{Introduction}

The aquaculture industry has progressed tremendously with the introduction of new technologies to the industry (Bilen et al. 2013). However, increasing stocking densities, other culture system intensification inevitably resulted in fish losses. Recently, several studies were conducted on fish health, including the importance of medicinal plants in increasing growth performance (Farahi et al. 2012; Heidarieh et al. 2013; Bahabadi et al. 2014; Sönmez et al. 2015a; Arslan et al. 2018; Cavdar et al. 2020), resistance to diseases (Nya \& Austin 2009) and also protection against some important fish pathogens, such as Lactococcus garvieae (Bilen et al. 2019a) and Aeromonas hydrophila (Bilen \& Elbeshti 2019) were evaluated after medicinal plant application. Also, increased antioxidant activity and improved health status were demonstrated (Sönmez et al. 2015b).

Veratrum album commonly known as the White Hellebore, is a characteristic plant of humid acid soils. It can form dense vegetations in a wide range of alpine habitats throughout Eurasia (Kleijn \& Steinger 2002). Veratrum plants usually produce a single preformed shoot per year and they have a single rhizome (Kleijn \& Steinger 2002). Veratrum contains a range of alkaloids (1.6-9\%) (Rätsch 2016).

Pomegranate fruits are commonly consumed fresh and in processed forms as wine, jams, and juice. Therefore, the by-product of the pomegranate juice industry, pomegranate peel, is a cheap output. Pomegranate peel accounts for roughly $50 \%$ of the fruit weight and it is known to contain high molecular weight phenolics, appreciable quantities of microelements, flavonoids, complex polysaccharides, proanthocyanidins, and ellagitannins. These compounds were reported to display strong apoptotic, antimicrobial, antioxidant, and anti-mutagenic properties (Seeram et al. 2005; Öztürk et al. 2018). Thus, it has been often utilized as a natural antioxidant in a variety of dietary supplements. 
With this background, these two plants were chosen as the materials of the study and it was aimed to examine the effects of pomegranate peel (Punica granatum) and veratrum (Veratrum album) on oxidative status, immune responses and digestive enzyme activity of rainbow trout (Oncorhynchus mykiss).

\section{Material and Methods}

\subsection{The fish and medicinal plants}

Experimental fish, (Oncorhynchus mykiss juveniles; initial weight: 6.22 g) were provided by Kastamonu University Inland and Marine Fish Production, Application and Research Centre, Turkey. Medicinal plants were procured from an herbal medicine shop at Kastamonu. Plants were shade-dried and aqueous methanolic extract was prepared following the protocol by Bilen et al. (2020). The extract was supplemented to the commercial trout feed by spraying and kept in $-20^{\circ} \mathrm{C}$ until further use.

\subsection{Experimental procedure}

All experiments were performed in Fisheries Faculty, Kastamonu University. All treatment groups were kept in 300 L recirculated aquarium systems following a completely randomized design. During the study period, $20 \%$ of the water was exchanged every day and the parameters were maintained at $17{ }^{\circ} \mathrm{C}$ temperature, $7.5 \mathrm{pH}, 8.0 \mathrm{mg} \mathrm{L}^{-1}$ oxygen at ambient photoperiod. After 2 weeks of acclimation period fish were fed with plant extract supplemented diets. Fish were fed twice in a day for 60 days of study. At every 20 day of the study, blood and liver tissues were collected to determine immunological and oxidative status of the test fish.

\subsection{Immune responses}

Non-specific immune responses, such as respiratory burst activity (Siwicki et al. 1994), lysozyme activity (Ellis 1990), and myeloperoxidase activity (Sahoo et al. 2005) were investigated as per the mentioned methodologies.

\subsection{Antioxidant activity}

Superoxide dismutase, catalase, glutathione peroxidase, and glucose 6 phosphate dehydrogenase activities were determined by using commercial kits (SIGMA 19160-1KT-F SOD assay kit, Cayman 707002 Catalase assay kit, Cayman 703102 glutathione peroxidase assay kit, and SPI-BIO0112 G6PDH activity assay kit, respectively).

\subsection{Digestive enzymes}

Digestive enzyme activities in the stomach and intestine were assayed after termination of the feeding trial. The stomach and intestine were thoroughly homogenized in ice-cold distilled water ten times their weight and centrifuged at $15000 \mathrm{~g}$ for 45 min at $4{ }^{\circ} \mathrm{C}$. The supernatant was used as a crude enzyme source. The $\alpha$-amylase activity was analysed by the starch hydrolysis method of Jiang \& Wang (2012) with some modifications. Lipase activity was assayed using the method described by German et al. (2004). Pepsin analysis was conducted according to the method reported by Worthington (1993). Enzyme trypsin analysis in the intestines was determined using $\mathrm{N}$-a-benzoyl-DL-arginine 4-nitroanilide hydrochloride as a substrate (Faulk et al. 2007) with minor modifications. Specific activities of all digestive enzymes were calculated as milligram of protein. All enzyme activities were calculated according to the equations below:

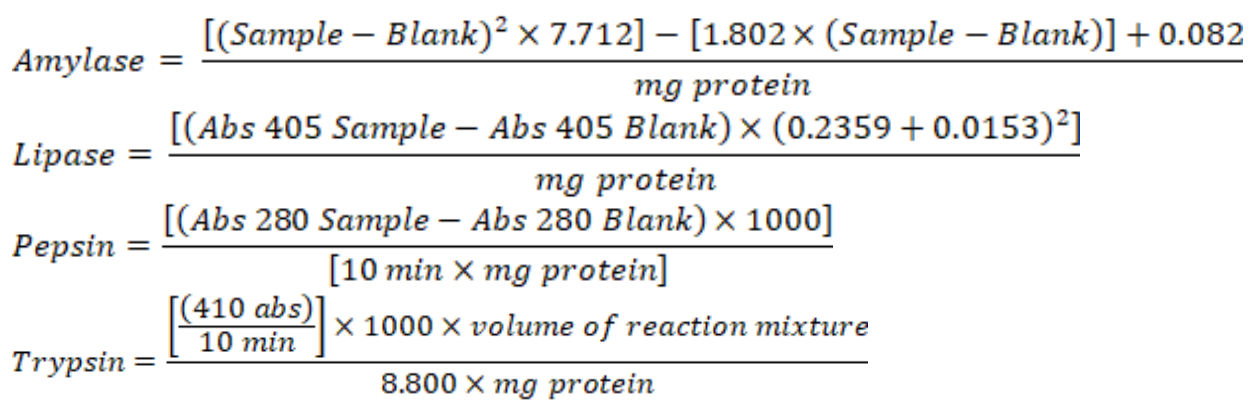

\subsection{Haematology}

Haematological parameters were assayed using the BC3000 Plus haematology analyser. WBC count was determined using haemocytometer (Blaxhall \& Daisley 1973). 


\subsection{Growth performance}

At the end of the experiment, all fish were weighed individually on a digital scale $(0.01 \mathrm{~g})$ to evaluate the FCR, SGR, final weight, and weight gain as follows:

Weight gain $(\mathrm{WG})=\mathrm{Wf}-\mathrm{Wi}$

Food conversion ratio $(\mathrm{FCR})=$ feed intake/weight gain

Specific growth rate $(\mathrm{SGR})=100 \times[(\ln W f-\ln W i) /$ days $]$

Where, Wi is mean initial weight and Wf is mean final weight.

\subsection{Statistical analyses}

All data were expressed as mean \pm SE (Standard error). Means were compared using one-way ANOVA. Homogeneity of variance was determined by using the Kolmogorov-Smirnov test and Levene's test. Comparisons between groups were performed by using Tukey's multiple range test with the significance level of 0.05 . Statistical analyses were conducted with SPSS software version 24.0 (IBM, NY, USA).

\section{Results}

\subsection{Immune responses}

In this 60-day study, respiratory burst, lysozyme, and myeloperoxidase activities were estimated using the blood and serum. The results are summarized in Figure 1. The results showed a decreased level on the $20^{\text {th }}$ day of the study in P500, P1000 and V1000 fish groups compared to control $(\mathrm{P}<0.05)$. No differences were observed in other groups' respiratory burst activity compared to the control $(\mathrm{P}>0.05)$. As the study progressed, respiratory burst activity in all experimental groups increased significantly except in P1000 and V1000 when compared to the control.

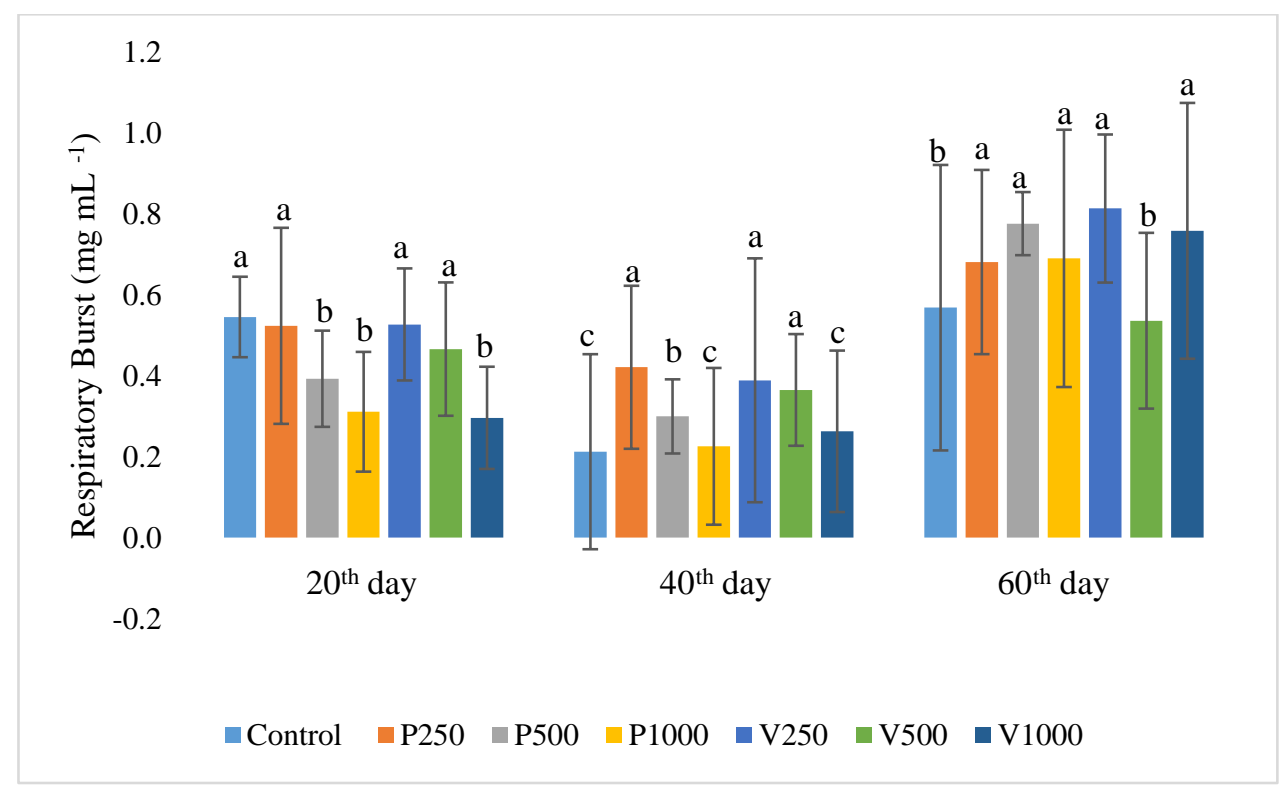

Figure 1- Respiratory burst activity in blood leucocytes of rainbow trout fed with methanolic extracts of pomegranate peel and veratrum. P250, P500, and P1000, extracts of pomegranate peel at 250,500 , and $1000 \mathrm{mg} \mathrm{kg}^{-1}$ diet, respectively; $\mathrm{V250}$, $V 500$, and $V 1000$, extracts of veratrum at 250,500 , and $1000 \mathrm{mg} \mathrm{kg}^{-1}$ diet, respectively. Values are presented as mean $\pm S E$. Different letters above columns express significant differences between groups $(\mathbf{P}<0.05)$

Results on lysozyme activity are displayed in Figure 2. In all experimental groups, lysozyme activity increased significantly on the $20^{\text {th }}$ and $40^{\text {th }}$ days of the study compared to the control. 


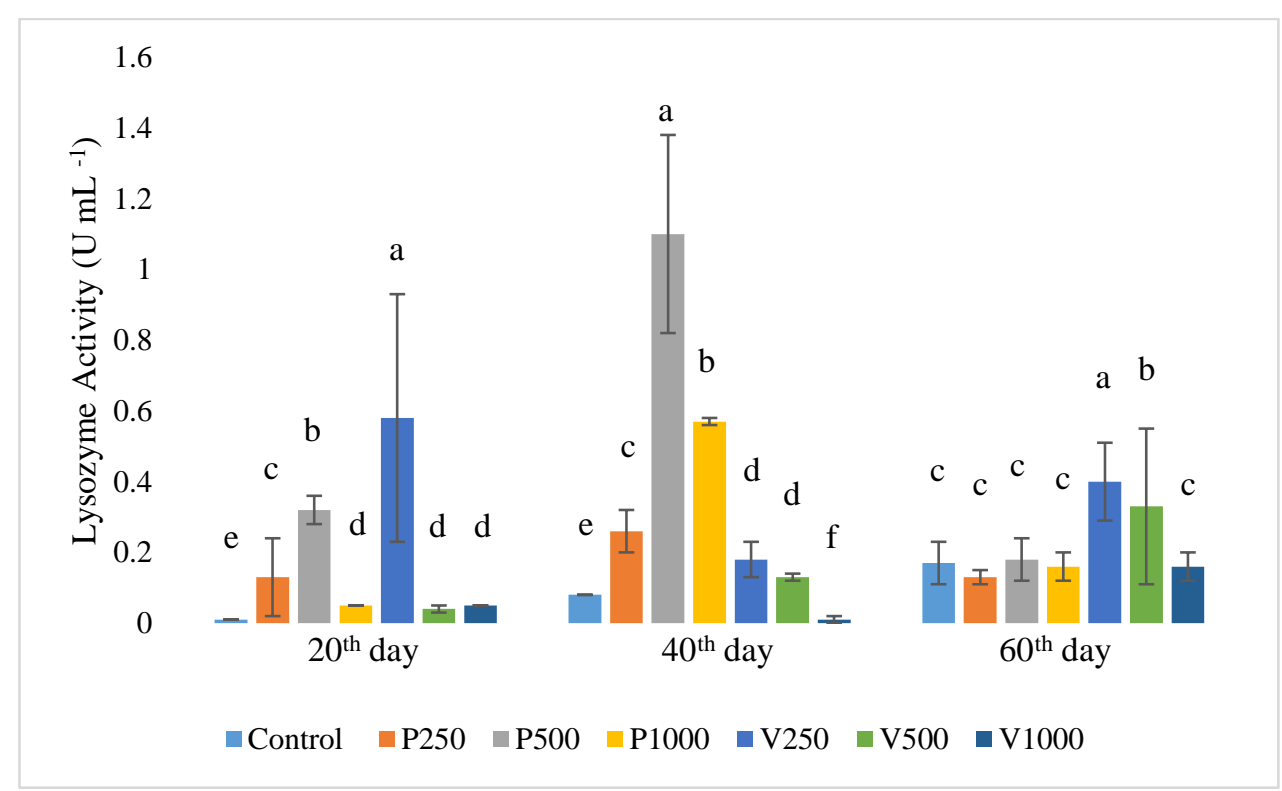

Figure 2- Lysozyme activity in blood leucocytes of rainbow trout fed with methanolic extracts of pomegranate peel and veratrum. P250, P500, and P1000, extracts of pomegranate peel at 250, 500, and $1000 \mathrm{mg} \mathrm{kg}^{-1}$ diet, respectively; V250, V500, and $\mathrm{V1000}$, extracts of veratrum at 250,500 , and $1000 \mathrm{mg} \mathrm{kg}^{-1}$ diet, respectively. Values are presented as mean $\pm \mathrm{SE}$.

Different letters above columns express significant differences between groups $(\mathbf{P}<0.05)$

Myeloperoxidase activity showed varying trends in different experimental groups (Figure 3.). Although, the MPO activity in the treated fish groups increased at the beginning, it decreased by the end of the study and significantly higher MPO activity was observed in the control group.

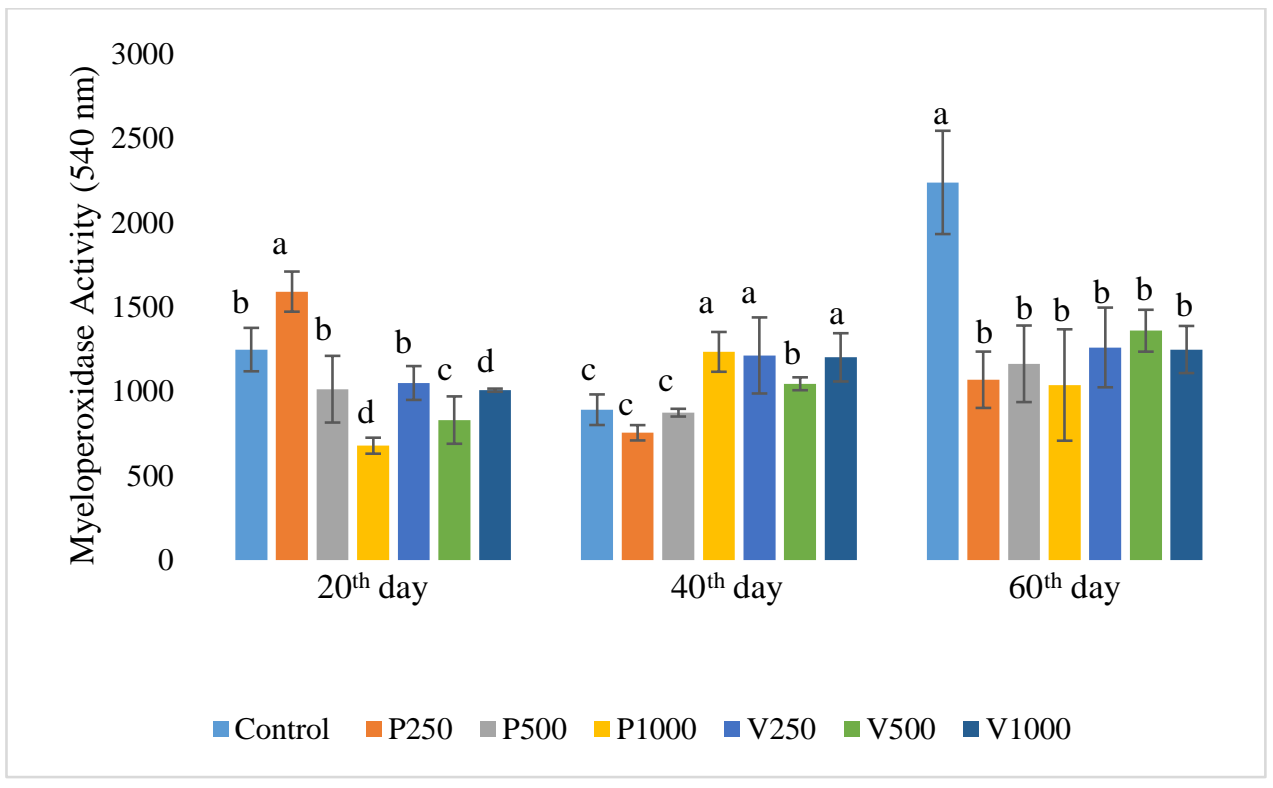

Figure 3- Myeloperoxidase activity in blood leucocytes of rainbow trout fed with methanolic extracts of pomegranate peel and veratrum. P250, P500, and P1000, extracts of pomegranate peel at 250,500 , and $1000 \mathrm{mg} \mathrm{kg}^{-1}$ diet, respectively; V250, V500, and $\mathrm{V1000}$, extracts of veratrum at 250,500 , and $1000 \mathrm{mg} \mathrm{kg}^{-1}$ diet, respectively. Values are presented as mean $\pm \mathrm{SE}$.

Different letters above columns express significant differences between groups $(\mathbf{P}<0.05)$

\subsection{Antioxidant activity}

SOD activity was found to increase in the groups P250 and P500 compared to other treatments and the control group on the $20^{\text {th }}$ day of the study $(\mathrm{P}<0.05)$ (Table 1). By the $40^{\text {th }}$ day of the study, SOD decreased only in the P1000 fish group. In all other groups, SOD increased and significantly higher values were observed from the V1000 group compared to that of the control $(\mathrm{P}<0.05)$. Similar to that, V1000 group showed the highest SOD activity on the $60^{\text {th }}$ day. Catalase activity had no differences at any sampling time in any treatment groups compared to the control $(\mathrm{P}>0.05)$ (Table 2). 
Table 1- Superoxide dismutase (SOD) activities in rainbow trout fed with pomegranate peel (Punica granatum) and veratrum (Veratrum album) extracts supplemented feed

\begin{tabular}{cccc}
\hline Groups & $\mathbf{2 0}^{\text {th }}$ Day & $\mathbf{4 0}^{\text {th }}$ Day & $\mathbf{6 O}^{\text {th }}$ Day \\
\hline Control & $89.25 \pm 19.70^{\mathrm{b}}$ & $65.63 \pm 17.41^{\mathrm{b}}$ & $44.76 \pm 5.24^{\mathrm{b}}$ \\
P250 & $125.88 \pm 19.26^{\mathrm{a}}$ & $102.56 \pm 7.53^{\mathrm{a}}$ & $30.60 \pm 10.08^{\mathrm{b}}$ \\
P500 & $180.66 \pm 41.92^{\mathrm{a}}$ & $95.82 \pm 18.21^{\mathrm{a}}$ & $31.81 \pm 5.24^{\mathrm{b}}$ \\
P1000 & $9.59 \pm 5.79^{\mathrm{c}}$ & $22.62 \pm 5.46^{\mathrm{c}}$ & $41.83 \pm 13.21^{\mathrm{b}}$ \\
V250 & $64.94 \pm 5.29^{\mathrm{b}}$ & $69.94 \pm 12.56^{\mathrm{b}}$ & $92.72 \pm 0.77^{\mathrm{a}}$ \\
V500 & $99.38 \pm 17.59^{\mathrm{b}}$ & $80.74 \pm 20.48^{\mathrm{a}}$ & $21.9 \pm 8.65^{\mathrm{b}}$ \\
V1000 & $60 \pm 9.49^{\mathrm{c}}$ & $128.02 \pm 10.90^{\mathrm{a}}$ & $104.3 \pm 13.5^{\mathrm{a}}$ \\
\hline
\end{tabular}

All data are given as mean $\pm \mathrm{SE}(\mathrm{n}=9)$; different letters in the same column denote statistically significant differences $(\mathrm{P}<0.05)$ between groups. $\mathrm{P} 250$, P500, and P1000, extracts of pomegranate peel at 250, 500, and $1000 \mathrm{mg} \mathrm{kg}^{-1}$ diet, respectively; V250, V500, and V1000, extracts of veratrum at 250,500 , and 1000 $\mathrm{mg} \mathrm{kg}^{-1}$ diet, respectively. The SOD activity is expressed as $\mathrm{U} / \mathrm{mL}$.

Table 2- Catalase (CAT) activities in rainbow trout fed with pomegranate peel (Punica granatum) and veratrum (Veratrum album) extracts supplemented feed

\begin{tabular}{cccc}
\hline Groups & $\mathbf{2 0}^{\text {th }}$ Day & $\mathbf{4 0}^{\text {th }}$ Day & $\mathbf{6 0}^{\text {th }}$ Day \\
\hline Control & $0.70 \pm 0.53$ & $0.73 \pm 0.29$ & $0.69 \pm 0.18$ \\
P250 & $0.43 \pm 0.03$ & $0.46 \pm 0.04$ & $0.49 \pm 0.05$ \\
P500 & $0.46 \pm 0.08$ & $0.50 \pm 0.00$ & $0.48 \pm 0.03$ \\
P1000 & $0.49 \pm 0.01$ & $0.66 \pm 0.17$ & $0.58 \pm 0.09$ \\
V250 & $0.36 \pm 0.03$ & $0.47 \pm 0.03$ & $0.40 \pm 0.02$ \\
V500 & $0.45 \pm 0.10$ & $0.61 \pm 0.05$ & $0.59 \pm 0.04$ \\
V1000 & $0.52 \pm 0.00$ & $0.44 \pm 0.03$ & $0.50 \pm 0.01$ \\
\hline
\end{tabular}

All data are given as mean $\pm \mathrm{SE}(\mathrm{n}=9)$; different letters in the same column denote statistically significant differences $(\mathrm{P}<0.05)$ between groups. $\mathrm{P} 250$, P500, and P1000, extracts of pomegranate peel at 250, 500, and $1000 \mathrm{mg} \mathrm{kg}^{-1}$ diet, respectively; V250, V500, and V1000, extracts of veratrum at 250, 500, and 1000 $\mathrm{mg} \mathrm{kg}^{-1}$ diet, respectively. The CAT activity is expressed as $\mathrm{nmol} / \mathrm{min} / \mathrm{mL}$.

Glucose-6-phosphatase dehydrogenase (G6PDH) activities were significantly elevated $(\mathrm{P}<0.05)$ in $\mathrm{P} 1000$, $\mathrm{P} 250$, and V500 fish groups compared to that in the control. In other groups, G6PDH was significantly decreased after the $20^{\text {th }}$ day of the study $(\mathrm{P}<0.05)$. On the $40^{\text {th }}$ day of the study, G6PDH activity significantly decreased in all treatment groups except $\mathrm{P} 1000$ compared to the control $(\mathrm{P}<0.05)$. On the $60^{\text {th }}$ day of the study, G6PDH values of P250 and V1000 were almost similar to the control $(\mathrm{P}>0.05)$ (Table 3).

Table 3- Glucose-6-phosphatase dehydrogenase (G6PDH) activities in rainbow trout fed with pomegranate peel (Punica granatum) and veratrum (Veratrum album) extracts supplemented feed

\begin{tabular}{llll}
\hline Groups & $\mathbf{2 0}^{\text {th }}$ Day & $\mathbf{4 0}^{\text {th }}$ Day & $\mathbf{6 O}^{\text {th }}$ Day \\
\hline Control & $0.67 \pm 0.01^{\mathrm{d}}$ & $0.90 \pm 0.03^{\mathrm{a}}$ & $0.85 \pm 0.02^{\mathrm{a}}$ \\
$\mathbf{P 2 5 0}$ & $0.87 \pm 0.01^{\mathrm{b}}$ & $0.75 \pm 0.01^{\mathrm{b}}$ & $0.92 \pm 0.01^{\mathrm{a}}$ \\
$\mathbf{P 5 0 0}$ & $0.57 \pm 0.01^{\mathrm{e}}$ & $0.72 \pm 0.01^{\mathrm{c}}$ & $0.64 \pm 0.01^{\mathrm{c}}$ \\
$\mathbf{P 1 0 0 0}$ & $1.05 \pm 0.01^{\mathrm{a}}$ & $0.82 \pm 0.02^{\mathrm{a}}$ & $0.68 \pm 0.00^{\mathrm{b}}$ \\
V250 & $0.72 \pm 0^{\mathrm{d}}$ & $0.69 \pm 0.02^{\mathrm{c}}$ & $0.73 \pm 0.02^{\mathrm{b}}$ \\
V500 & $0.79 \pm 0.01^{\mathrm{c}}$ & $0.74 \pm 0^{\mathrm{b}}$ & $0.62 \pm 0.01^{\mathrm{c}}$ \\
V1000 & $0.67 \pm 0^{\mathrm{d}}$ & $0.67 \pm 0^{\mathrm{c}}$ & $0.84 \pm 0^{\mathrm{a}}$
\end{tabular}

All data are given as mean $\pm \mathrm{SE}(\mathrm{n}=9)$; different letters in the same column denote statistically significant differences (P<0.05) between groups. $\mathrm{P} 250$, $\mathrm{P} 500$, and $\mathrm{P} 1000$, extracts of pomegranate peel at 250,500 , and $1000 \mathrm{mg} \mathrm{kg}^{-1}$ diet, respectively; V250, V500, and V1000, extracts of veratrum at 250,500 , and 1000 $\mathrm{mg} \mathrm{kg}^{-1}$ diet, respectively. The G6PDH activity is expressed as $\mathrm{nmol} / \mathrm{min} / \mathrm{mL}$.

Glutathione peroxidase (GPx) activities in rainbow trout fed with different doses of experimental plants are shown in Table 4. The highest GPx activity was determined in V500 and V1000 compared to the control. The decrease in GPx activity was determined on the $40^{\text {th }}$ day of study in P250 and V1000 groups compared to the control $(\mathrm{P}<0.05)$. No significant differences were observed in treatment groups compared to the control on the $60^{\text {th }}$ day $(\mathrm{P}>0.05)$. 
Table 4- Glutathione peroxidase (GPx) activities in rainbow trout fed with pomegranate peel (Punica granatum) and veratrum (Veratrum album) extracts supplemented feed

\begin{tabular}{llll}
\hline Groups & $\mathbf{2 0}^{\text {th }}$ Day & $\mathbf{4 0}^{\text {th }}$ Day & $\mathbf{6 O}^{\text {th }}$ Day \\
\hline Control & $103.02 \pm 5.14^{\mathrm{b}}$ & $105.73 \pm 10.52^{\mathrm{a}}$ & $90.01 \pm 0.91$ \\
P250 & $57.62 \pm 7.16^{\mathrm{c}}$ & $36.16 \pm 9.41^{\mathrm{c}}$ & $97.02 \pm 0.41$ \\
P500 & $47.98 \pm 9.85^{\mathrm{c}}$ & $118.15 \pm 19.13^{\mathrm{a}}$ & $89.02 \pm 0.72$ \\
P1000 & $4.18 \pm 0.57^{\mathrm{d}}$ & $94.97 \pm 5.26^{\mathrm{a}}$ & $91.01 \pm 0.30$ \\
V250 & $51.39 \pm 13.50^{\mathrm{c}}$ & $90.53 \pm 11.50^{\mathrm{a}}$ & $93.02 \pm 0.56$ \\
V500 & $127.78 \pm 11.72^{\mathrm{a}}$ & $104.87 \pm 7.05^{\mathrm{a}}$ & $95.03 \pm 0.01$ \\
V1000 & $163.96 \pm 28.42^{\mathrm{a}}$ & $76.34 \pm 6.17^{\mathrm{b}}$ & $91.01 \pm 0.45$ \\
\hline
\end{tabular}

All data are given as mean $\pm \mathrm{SE}(\mathrm{n}=9)$; different letters in the same column denote statistically significant differences $(\mathrm{P}<0.05)$ between groups. P250, P500, and P1000, extracts of pomegranate peel at 250, 500, and $1000 \mathrm{mg} \mathrm{kg}^{-1}$ diet, respectively; V250, V500, and V1000, extracts of veratrum at 250,500 , and 1000 $\mathrm{mg} \mathrm{kg}^{-1}$ diet, respectively. The GPx activity is expressed as $\mathrm{nmol} / \mathrm{min} / \mathrm{mL}$.

Lipid peroxidation on the white muscle of the treated fish groups is presented in Table 5. MDA content was significantly decreased in V250, P1000 and V1000 fish groups on the $20^{\text {th }}$ day. On the $40^{\text {th }}$ day of the study, $\mathrm{P} 1000$ had lowest value $(\mathrm{P}<0.05)$. Only P250 and P500 groups' MDA levels were similar to that of the control $(\mathrm{P}>0.05)$. In all other groups, MDA activity decreased significantly. A significant decrease in MDA levels was determined in P250 and V500 fish groups on the $60^{\text {th }}$ day of study compared to that of the control $(\mathrm{P}<0.05)$.

Table 5- Malondialdehyde (MDA) levels in rainbow trout livers fed with pomegranate peel (Punica granatum) and veratrum (Veratrum album) extracts supplemented feed

\begin{tabular}{llll}
\hline Groups & $\mathbf{2 0}^{\text {th }}$ Day & $\mathbf{4 0}^{\text {th }}$ Day & $\mathbf{6 0}^{\text {th }}$ Day \\
\hline Control & $5.45 \pm 0.13^{\mathrm{b}}$ & $5.08 \pm 0.16^{\mathrm{ab}}$ & $5.00 \pm 0.23^{\mathrm{a}}$ \\
P250 & $7.02 \pm 0.17^{\mathrm{a}}$ & $5.89 \pm 0.18^{\mathrm{a}}$ & $3.91 \pm 0.08^{\mathrm{b}}$ \\
P500 & $5.44 \pm 0.19^{\mathrm{b}}$ & $5.11 \pm 0.10^{\mathrm{ab}}$ & $4.35 \pm 0.15^{\mathrm{a}}$ \\
P1000 & $3.87 \pm 0.41^{\mathrm{c}}$ & $2.56 \pm 0.18^{\mathrm{c}}$ & $4.77 \pm 0.48^{\mathrm{a}}$ \\
V250 & $2.51 \pm 0.09^{\mathrm{d}}$ & $2.95 \pm 0.13^{\mathrm{c}}$ & $5.17 \pm 0.2^{\mathrm{a}}$ \\
V500 & $5.80 \pm 0.2^{\mathrm{b}}$ & $4.21 \pm 0.27^{\mathrm{b}}$ & $3.46 \pm 0.19^{\mathrm{b}}$ \\
V1000 & $4.01 \pm 0.10^{\mathrm{c}}$ & $4.53 \pm 0.17^{\mathrm{b}}$ & $4.44 \pm 0.29^{\mathrm{a}}$ \\
\hline
\end{tabular}

All data are given as mean $\pm \mathrm{SE}(\mathrm{n}=9)$; different letters in the same column denote statistically significant differences $(\mathrm{P}<0.05)$ between groups. P250, P500, and P1000, extracts of pomegranate peel at 250,500 , and $1000 \mathrm{mg} \mathrm{kg}^{-1}$ diet, respectively; V250, V500, and V1000, extracts of veratrum at 250 , 500 , and 1000 $\mathrm{mg} \mathrm{kg}^{-1}$ diet, respectively. MDA levels are expressed as $\mathrm{nmol} / \mathrm{min} / \mathrm{mL}$.

\subsection{Digestive enzymes}

Pepsin activity was determined at the end of study (Figure 4.). The highest pepsin activity was observed in the P250 fish group $(\mathrm{P}<0.05)$. While no differences were observed in P500 and control groups, all other groups' pepsin activity was significantly decreased compared to the control. 
350

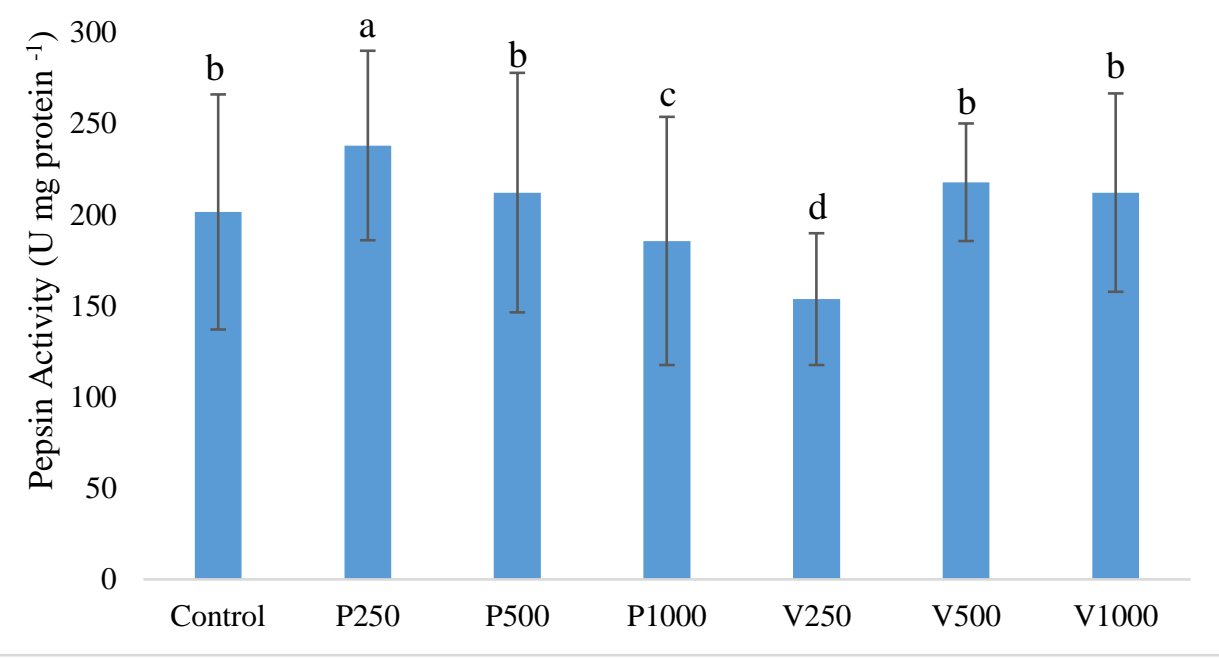

Figure 4- Pepsin activity in rainbow trout fed with methanolic extracts of pomegranate peel and veratrum. P250, P500, and P1000, extracts of pomegranate peel at 250,500 , and $1000 \mathrm{mg} \mathrm{kg}^{-1}$ diet, respectively; V250, V500, and V1000, extracts of veratrum at 250,500 , and $1000 \mathrm{mg} \mathrm{kg}^{-1}$ diet, respectively. Values are presented as mean $\pm \mathrm{SD}$. Different letters above columns express significant differences between groups $(\mathbf{P}<0.05)$

Trypsin activity was higher than control only in the $\mathrm{P} 1000$ group $(\mathrm{P}<0.05)$ and in $\mathrm{P} 500$ group, no difference was observed compared to the control (Figure 5). However, in all other groups, trypsin activity significantly decreased.

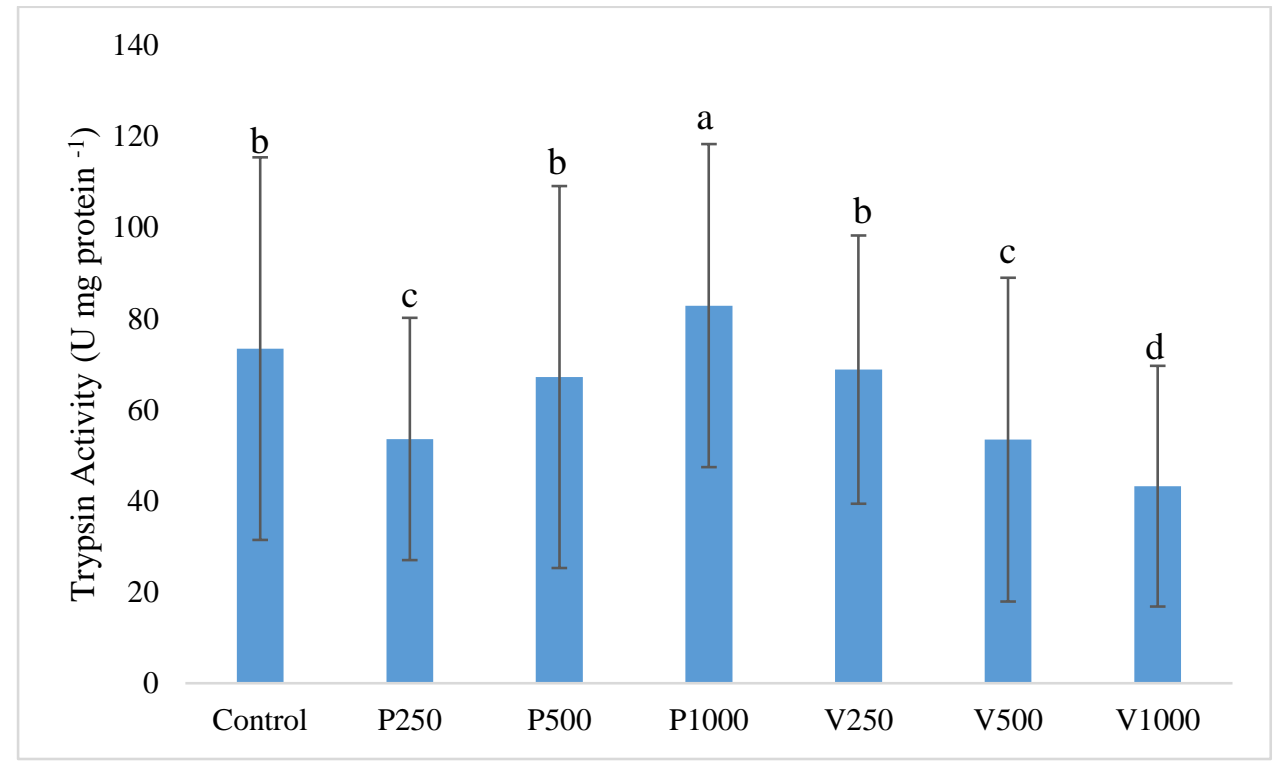

Figure 5- Trypsin activity in rainbow trout fed with methanolic extracts of pomegranate peel and veratrum. P250, P500, and $\mathrm{P1000}$, extracts of pomegranate peel at 250,500 , and $1000 \mathrm{mg} \mathrm{kg}^{-1}$ diet, respectively; V250, V500, and V1000, extracts of veratrum at 250,500 , and $1000 \mathrm{mg} \mathrm{kg}^{-1}$ diet, respectively. Values are presented as mean $\pm \mathrm{SD}$. Different letters above columns express significant differences between groups $(\mathbf{P}<0.05)$

Lipase activity showed no significant differences among the treated fish groups (Figure 6.). 


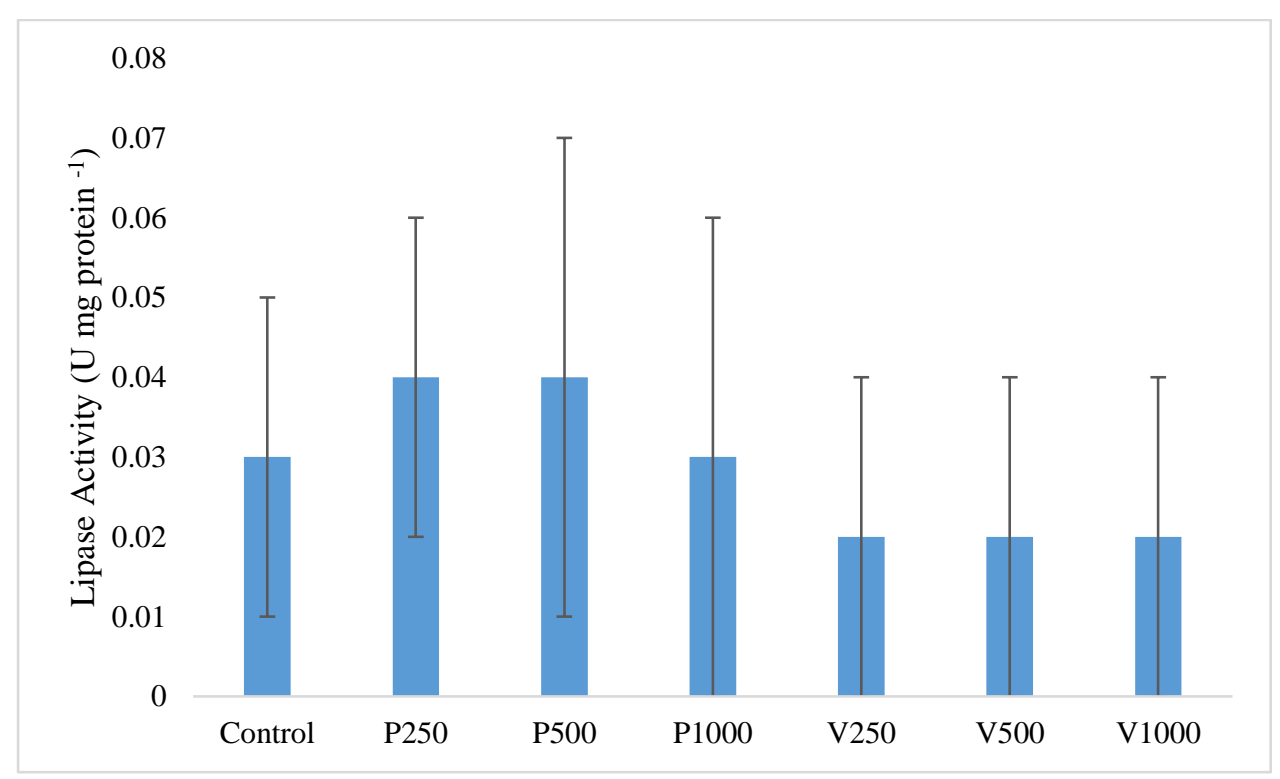

Figure 6- Lipase activity in rainbow trout fed with methanolic extracts of pomegranate peel and veratrum. P250, P500, and

$P 1000$, extracts of pomegranate peel at 250,500 , and $1000 \mathrm{mg} \mathrm{kg}^{-1}$ diet, respectively; V250, V500, and V1000, extracts of veratrum at 250,500 , and $1000 \mathrm{mg} \mathrm{kg}^{-1}$ diet, respectively. Values are presented as mean $\pm \mathrm{SD}$. Different letters above columns express significant differences between groups $(\mathrm{P}<0.05)$

Amylase activity data are presented in Figure 7. In all treated fish groups, amylase activity decreased significantly.

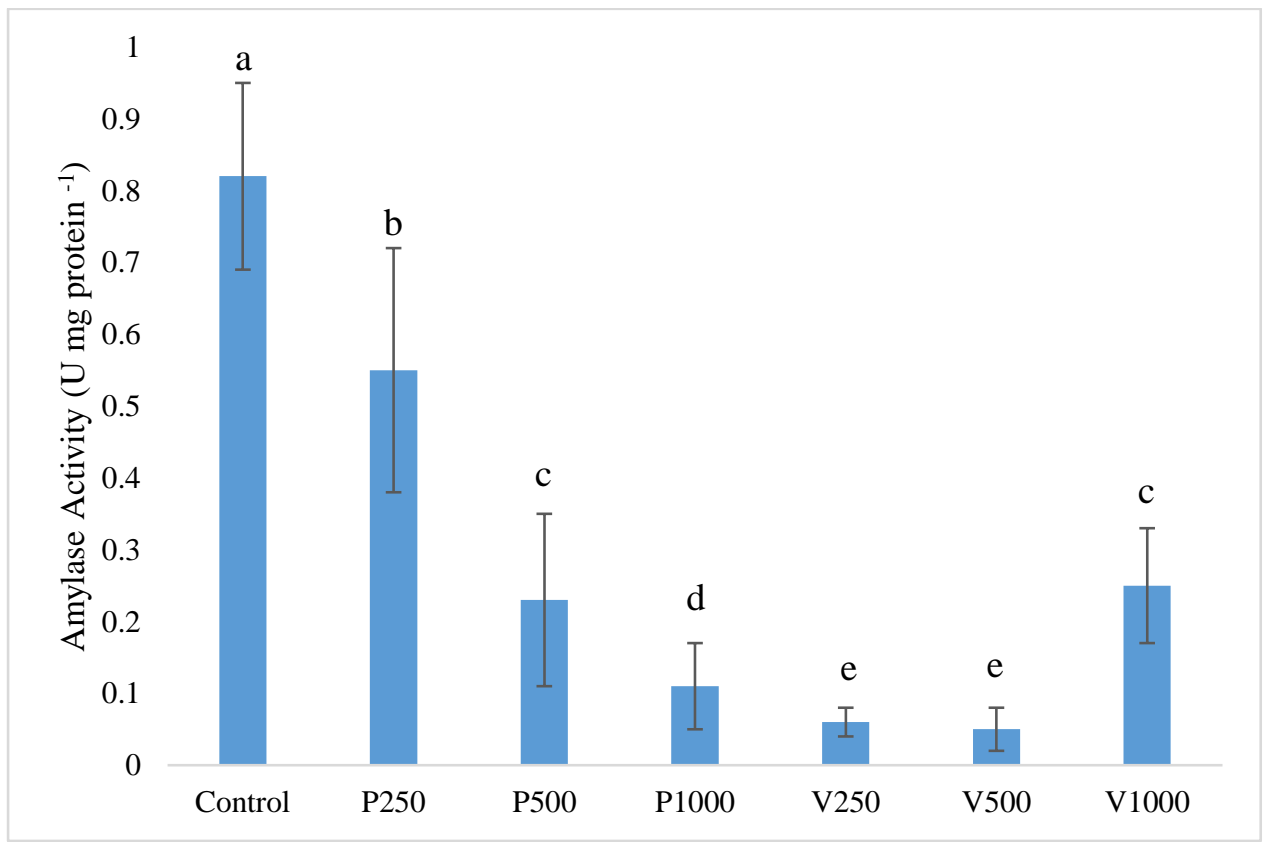

Figure 7- Amylase activity in rainbow trout fed with methanolic extracts of pomegranate peel and veratrum. P250, P500, and

$P 1000$, extracts of pomegranate peel at 250,500 , and $1000 \mathrm{mg} \mathrm{kg}^{-1}$ diet, respectively; V250, V500, and V1000, extracts of veratrum at 250,500 , and $1000 \mathrm{mg} \mathrm{kg}^{-1}$ diet, respectively. Values are presented as mean $\pm \mathrm{SD}$. Different letters above columns express significant differences between groups $(\mathbf{P}<0.05)$

\subsection{Haematology}

Results on haematological responses are given in Table 6. Results showed a decreased WBC count in the P1000 fish group compared to that of the control $(\mathrm{P}<0.05)$. No significant differences were observed for RBC count among all the treatment groups $(\mathrm{P}>0.05)$. Haemoglobin content was significantly higher in the $\mathrm{P} 250$ group compared to the control. Other groups' haemoglobin contents did not show any differences compared to the control $(\mathrm{P}>0.05)$. Haematocrit values decreased significantly in $\mathrm{P} 500$ and V250 compared to the control $(\mathrm{P}<0.05)$. 
Table 6- Haematological responses of rainbow trout fed with pomegranate peel (Punica granatum) and veratrum (Veratrum album) extracts supplemented feed

\begin{tabular}{cccccccc}
\hline Groups & $\boldsymbol{W B C}$ & $\boldsymbol{R B C}$ & $\boldsymbol{H} \boldsymbol{G B}$ & $\boldsymbol{H C T}$ & $\boldsymbol{M C V}$ & $\boldsymbol{M C H}$ & $\boldsymbol{M C H C}$ \\
\hline Control & $75.1 \pm 12^{\mathrm{a}}$ & $1.60 \pm 0.09$ & $10.10 \pm 0.50^{\mathrm{b}}$ & $30.20 \pm 2.40^{\mathrm{a}}$ & $189.45 \pm 5.15$ & $63.25 \pm 0.25$ & $335.00 \pm 10.00$ \\
P250 & $77.2 \pm 12.5^{\mathrm{a}}$ & $1.89 \pm 0.38$ & $13.15 \pm 0.69^{\mathrm{a}}$ & $36.35 \pm 10.28^{\mathrm{a}}$ & $213.00 \pm 9.74$ & $65.27 \pm 7.01$ & $306.50 \pm 23.51$ \\
P500 & $65.1 \pm 13.4^{\mathrm{a}}$ & $1.30 \pm 0.09$ & $8.50 \pm 0.10^{\mathrm{b}}$ & $18.92 \pm 10.11^{\mathrm{b}}$ & $213.35 \pm 10.45$ & $77.73 \pm 11.40$ & $368.50 \pm 73.12$ \\
P1000 & $54.23 \pm 8.57^{\mathrm{b}}$ & $1.42 \pm 0.08$ & $9.54 \pm 0.21^{\mathrm{b}}$ & $27.68 \pm 6.08^{\mathrm{a}}$ & $212.75 \pm 5.16$ & $67.97 \pm 3.08$ & $320.00 \pm 15.18$ \\
V250 & $81.21 \pm 2.14^{\mathrm{a}}$ & $1.43 \pm 0.12$ & $9.30 \pm 0.54^{\mathrm{b}}$ & $18.80 \pm 12.83^{\mathrm{b}}$ & $195.10 \pm 6.97$ & $65.60 \pm 6.96$ & $336.25 \pm 28.71$ \\
V500 & $80.21 \pm 2.38^{\mathrm{a}}$ & $1.38 \pm 0.11$ & $8.44 \pm 0.71^{\mathrm{b}}$ & $26.18 \pm 4.22^{\mathrm{a}}$ & $202.28 \pm 5.40$ & $62.07 \pm 3.73$ & $307.67 \pm 17.28$ \\
V1000 & $79.32 \pm 7.68^{\mathrm{a}}$ & $1.40 \pm 0.01$ & $7.98 \pm 0.73^{\mathrm{b}}$ & $24.38 \pm 4.72^{\mathrm{a}}$ & $203.32 \pm 5.35$ & $51.10 \pm 18.07$ & $293.40 \pm 15.69$ \\
\hline
\end{tabular}

All data are given as mean $\pm \mathrm{SE}(\mathrm{n}=9)$; different letters in the same column denote statistically significant differences $(\mathrm{P}<0.05)$ between groups. $\mathrm{P} 250$, $\mathrm{P} 500$, and P1000, extracts of pomegranate peel at 250, 500, and $1000 \mathrm{mg} \mathrm{kg}^{-1}$ diet, respectively; V250, V500, and V1000, extracts of veratrum at 250,500 , and 1000 $\mathrm{mg} \mathrm{kg}^{-1}$ diet, respectively.

\subsection{Growth performance}

Growth performances are summarized in Table 7. The final weight of fish significantly decreased $(\mathrm{P}<0.05)$ in all treatment groups except P1000 compared to the control. The lowest growth was recorded in veratrum administered groups $(\mathrm{P}<0.05)$. Similar results were observed on weight gain and SGR values $(\mathrm{P}<0.05)$. However, interestingly, FCR decreased significantly in the P500 fish group compared to the control $(\mathrm{P}<0.05)$.

Table 7- Changes at the end of the study (60 day) in growth performance of rainbow trout fed with pomegranate peel (Punica granatum) and veratrum (Veratrum album) extracts supplemented feed

\begin{tabular}{llllllll}
\hline Parameter & Control & P250 & P500 & P1000 & V250 & V500 & V1000 \\
\hline Initial Weight (g) & $6.22 \pm 0.3$ & $6.42 \pm 0.1$ & $6.13 \pm 0.2$ & $6.19 \pm 0.2$ & $6.02 \pm 0.3$ & $6.36 \pm 0.4$ & $6.45 \pm 0.3$ \\
Final Weight (g) & $27.64 \pm 1.8^{\mathrm{a}}$ & $22.57 \pm 0.57^{\mathrm{b}}$ & $23.48 \pm 1.54^{\mathrm{b}}$ & $25.13 \pm 3.1^{\mathrm{a}}$ & $20.02 \pm 1.47^{\mathrm{c}}$ & $19.98 \pm 0.55^{\mathrm{c}}$ & $13.38 \pm 3.59^{\mathrm{d}}$ \\
WG $(\%)$ & $216.9 \pm 5.24^{\mathrm{a}}$ & $149.68 \pm 2.42^{\mathrm{b}}$ & $182.68 \pm 15.15^{\mathrm{b}}$ & $198.03 \pm 16.38^{\mathrm{a}}$ & $157.80 \pm 22.9^{\mathrm{c}}$ & $133.05 \pm 8.59^{\mathrm{c}}$ & $94.60 \pm 33.85^{\mathrm{d}}$ \\
FCR & $0.96 \pm 0.23^{\mathrm{b}}$ & $0.91 \pm 0.11^{\mathrm{b}}$ & $0.75 \pm 0.08^{\mathrm{c}}$ & $0.99 \pm 0.48^{\mathrm{a}}$ & $0.89 \pm 0.02^{\mathrm{b}}$ & $0.95 \pm 0.07^{\mathrm{b}}$ & $1.00 \pm 0.07^{\mathrm{a}}$ \\
SGR (\%) & $2.48 \pm 0.11^{\mathrm{a}}$ & $2.15 \pm 0.04^{\mathrm{b}}$ & $2.21 \pm 0.11^{\mathrm{b}}$ & $2.31 \pm 0.21^{\mathrm{a}}$ & $1.94 \pm 0.12^{\mathrm{c}}$ & $1.94 \pm 0.05^{\mathrm{c}}$ & $1.21 \pm 0.46^{\mathrm{d}}$ \\
\hline
\end{tabular}

All data are given as mean $\pm \mathrm{SE}$; different letters in the same column denote statistically significant differences ( $<<0.05)$ between groups. $\mathrm{P} 250$, P500, and $\mathrm{P} 1000$, extracts of pomegranate peel at 250,500 , and $1000 \mathrm{mg} \mathrm{kg}^{-1}$ diet, respectively; V250, V500, and V1000, extracts of veratrum at 250,500 , and $1000 \mathrm{mg}$ $\mathrm{kg}^{-1}$ diet, respectively.

\section{Discussion}

In the present study, growth performances were negatively affected after the fish were fed with feeds supplemented with varying doses of pomegranate peel and veratrum aqueous methanolic extracts. On the contrary, positive effects were observed on immune response and antioxidant activity on such supplementations.

Respiratory burst is an activity that results after the production of several reactive oxygen molecules by neutrophils (Moritomo et al. 2003) and it is an important adaptive immune parameter in such studies (Bilen et al. 2019b). In the present study, the respiratory burst gradually increased in all experimental groups over time. Similar results were found in different fish species treated with other medicinal plant extracts (Amhamed et al. 2018; Mohamed et al. 2018). In line with our study, increased activity was determined in rainbow trout fed with different medicinal plants, such as Rheum officinale, Panax ginseng, Origanum vulgare, Lavandula officinalis, Echinacea purpurea, Curcuma longa, and Aloe vera (Bulfon et al. 2018). Lysozyme is an also important defense molecule of the fish (Bilen \& Elbeshti 2019; Saurabh \& Sahoo 2008). In the present study, lysozyme activity showed an increasing trend over the entire study period and this indicated that both the plant extracts contributed to such increase over 40 days of study. The medicinal plant has positive effects on lysozyme activity (Almabrok et al. 2018). Veratrum has an active ingredient known as dihydro-veratramine (Wilson et al. 2010) which is very close to cyclopamine which acts as the hedgehog signaling pathway inhibitor element (Reya et al. 2001). Cyclopamine has been reported to affect the innate immune system in rainbow trout (Sönmez et al. 2018). We believe that this content should be responsible for lysozyme activity. At the end of the study, in all treatment groups, MPO activity was found to decrease significantly. A similar trend of MPO activity was observed in rainbow trout fed with lemon balm (Bilen et al. 2019c). However, contrasting results were obtained for Cyprinus carpio and seabass fed with Malva sylvestris (Bilen et al. 2019b; Bilen et al. 2019d). 
Antioxidant system plays an important role in elimination of reactive oxygen species (ROS), thereby preventing cell damage (Hoseinifar et al. 2020). In the present study, SOD activity in the P250 and P500 groups has increased, while no significant differences were observed in CAT activity. After feeding for 20 days, almost all groups showed an elevated G6PDH activity, while V500 and V1000 supplementation significantly increased GPx activity. Interestingly MDA levels decreased only in P1000 and V250 fish groups. MDA is well known as an oxidative stress indicator (Fang et al. 2002). It appears from the study that a low dose of veratrum and a high dose of pomegranate peel has antioxidative properties. The results are in line with the antioxidant activity of Psidium guajava leaf extracts in Oreochromis mossambicus (Gobi et al. 2016), and sage and thyme oil in rainbow trout (Sönmez et al. 2015b).

Digestive enzymes are important markers to determine differences in growth performance in fish. In the present study, amylase activity was lower in all of the treatment groups than in the control. Amylase increases after glycogen and starch are introduced into the digestive system and are more active in omnivore fish species, suggestive of its lower values for rainbow trout. No differences were observed in amylase activity after rainbow trout fed with stinging nettle (Urtica dioica), mango (Mangifera indica), and lupin (Lupinus perennis) (Awad et al. 2012).

Lipase is secreted by the pancreas and has a major role in lipid catabolism (Awad et al. 2012). No difference was observed in lipase activity in the present study as the experimental diets have similar fat contents. However, increased lipase activity was determined after lemon balm administration (Bilen et al. 2019c). In the present study, a higher level of trypsin activity was found in the P1000 fish group. However, no difference was observed after Ergosan administration in rainbow trout (Heidarieh et al. 2012).

Haematological parameters are important indicators to determine fish health. In the present study, WBC count increased in veratrum administered groups, while RBC and $\mathrm{HBG}$ decreased. It can be opined that an inflammatory response could have started after veratrum usage. Similar to this result, an increased WBC count was determined in rainbow trout after Melissa officinalis (Farahi et al. 2012) and Echinacea purpurea treatments (Oskoii et al. 2012).

Growth performance in the present study was affected negatively, especially in veratrum groups. However, it is interesting to note that FCR in the P500 group showed a diminishing trend. Similar to our FCR result, Heidarieh et al. (2013) found a decrease in FCR value in rainbow trout fed with different doses of Aloe vera. In contrast to our growth performance results, Ngugi et al. (2015), Adel et al. (2017), and Nobahar et al. (2015) found an increase in rainbow trout fed with different doses of medicinal plants. No difference was observed after the administration of ribwort plantain (Elbesthi et al. 2020).

\section{Conclusions}

Both Veratrum album and pomegranate peel extract supplementation at varying doses increased the overall immune status and antioxidant activities of rainbow trout fingerlings in a short period. Although all results were obtained under laboratory conditions, it may be suggested that short-term usage of feed supplemented especially with pomegranate peel extract could be used to improve immune responses. However, its long-term usage is not suggested. High doses of veratrum are not suggested as an additive at all. Pomegranate peel, when supplemented at $500 \mathrm{mg} / \mathrm{kg}$, in particular, can be beneficial as it lowers the FCR and improves the overall feed efficiency. Long-term effects are yet to be determined for different fish and feed combinations as these by-products of the food industry have huge potentials to be included in the fish feed as additives. Further studies may investigate the effects of these plant extracts on disease resistance.

\section{References}

Adel M, Caipang C M A \& Dawood M A (2017). Immunological responses and disease resistance of rainbow trout (Oncorhynchus mykiss) juveniles following dietary administration of stinging nettle (Urtica dioica). Fish \& Shellfish Immunology 71: 230-238. https://doi.org/10.1016/j.fsi.2017.10.016

Almabrok A A, Amhamed I D, Mohamed G A, Bilen S \& Altief T A S (2018). Effect of Tilia tomentosa methanolic extract on growth performance, digestive enzyme activity, immune system and haematological indices of common carp (Cyprinus carpio). Marine Science and Technology Bulletin 7(1): 12-20. https://doi.org/10.33714/masteb.421047

Amhamed I D, Mohamed G A, Almabrok A A, Altief T A S \& Bilen S (2018). Efficacy of Dietary Chenopodium album Extract on Some Health Parameters, Digestive Enzymes and Growth Performance in Juvenile Cyprinus carpio. Alinteri Zirai Bilimler Dergisi 33(2): 165176. https://doi.org/10.28955/alinterizbd.412455

Arslan G, Sönmez A Y \& Yanık T (2018). Effects of grape Vitis vinifera seed oil supplementation on growth, survival, fatty acid profiles, antioxidant contents and blood parameters in rainbow trout Oncorhynchus mykiss. Aquaculture Research 49(6): $2256-2266$. https://doi.org/10.1111/are.13686

Awad E, Austin B \& Lyndon A (2012). Effect of dietary supplements on digestive enzymes and growth performance of rainbow trout (Oncorhynchus mykiss, Walbaum). Journal of American Science 8(12): 858-864

Bahabadi M N, Banaee M, Taghiyan M \& Haghi B N (2014). Effects of dietary administration of yarrow extract on growth performance and blood biochemical parameters of rainbow trout (Oncorhynchus mykiss). International Journal of Aquatic Biology 2(5): 275-285

Bilen S \& Elbeshti H T A G (2019). A new potential therapeutic remedy against Aeromonas hydrophila infection in rainbow trout (Oncorhynchus mykiss) using tetra, Cotinus coggygria. Journal of Fish Diseases 42(10): 1369-1381. https://doi.org/10.1111/jfd.13061 
Bilen S, Altief T A S, Yürüten Özdemir K, Salem M O A, Terzi E \& Güney K (2019c). Effect of lemon balm (Melissa officinalis) extract on growth performance, digestive and antioxidant enzyme activities, and immune responses in rainbow trout (Oncorhynchus mykiss). Fish Physiology and Biochemistry 46(1): 471-481. https://doi.org/10.1007/s10695-019-00737-z

Bilen S, Filogh A M, Ali A B, Kenanoğlu O N \& Zoral M A (2019b). Effect of common mallow (Malva sylvestris) dietary supplementation on growth performance, digestive enzyme activities, haemotological and immune responses of common carp (Cyprinus carpio). Aquaculture International 28: 73-84. https://doi.org/10.1007/s10499-019-00444-9

Bilen S, Karga M, Celik Altunoglu Y, Ulu F \& Biswas G (2020). Immune responses and growth performance of the aqueous methanolic extract of Malva sylvestris in Oncorhynchus mykiss. Marine Science and Technology Bulletin 9(2): 159-167. https://doi.org/10.33714/masteb.746951

Bilen S, Kenanoglu O N, Terzi E, Ozdemir R C \& Sonmez A Y (2019d). Effects of tetra (Cotinus coggygria) and common mallow (Malva sylvestris) plant extracts on growth performance and immune response in Gilthead Sea bream (Sparus aurata) and European Sea bass (Dicentrarchus labrax). Aquaculture 512: 734251. https://doi.org/10.1016/j.aquaculture.2019.734251

Bilen S, Kizak V \& Gezen A M (2013). Floating fish farm unit (3FU). Is it an appropriate method for Salmonid production? Marine Science and Technology Bulletin 2(1): 9-13

Bilen S, Sirtiyah A M A \& Terzi E (2019a). Therapeutic effects of beard lichen, Usnea barbata extract against Lactococcus garvieae infection in rainbow trout (Oncorhynchus mykiss). Fish \& Shellfish Immunology 87: 401-409. https://doi.org/10.1016/j.fsi.2019.01.046

Blaxhall P \& Daisley K (1973). Routine haematological methods for use with fish blood. Journal of Fish Biology 5(6): 771-781. https://doi.org/10.1111/j.1095-8649.1973.tb04510.x

Bulfon C, Galeotti M \& Volpatti D (2018). Medicinal plant extracts modulate respiratory burst and proliferation activity of rainbow trout (Oncorhynchus mykiss) leukocytes. Fish Physiology and Biochemistry 44(1): 109-117. https://doi.org/10.1007/s10695-017-0417-5

Cavdar N, Aktas M \& Genc E (2020). Effects of Marigold (Tagetes erecta) and Synthetic Carotenoid on Growth Performance and Skin Coloration of Blue Streak Hap (Labidochromis caeruleus) and Pindani (Pseudotropheus socolofi) Fry (Cichlidae). Journal of Agricultural Sciences 26(3): 307-315. https://doi.org/10.15832/ankutbd.523112

Elbesthi R T A, Yürüten Özdemir K, Taştan Y, Bilen S \& Sönmez A Y (2020). Effects of ribwort plantain (Plantago lanceolata) extract on blood parameters, immune response, antioxidant enzyme activities, and growth performance in rainbow trout (Oncorhynchus mykiss). Fish Physiology and Biochemistry 46(4): 1295-1307. https://doi.org/10.1007/s10695-020-00790-z

Ellis A E (1990). Lysozyme assays. Techniques in Fish Immunology 1: 101-103

Fang Y Z, Yang S \& Wu G (2002). Free radicals, antioxidants, and nutrition. Nutrition 18(10): 872-879. https://doi.org/10.1016/S08999007(02)00916-4

Farahi A, Kasiri M, Sudagar M, Soleimani Iraei M \& Zorriehzahra S (2012). Effect of dietary supplementation of Melissa officinalis and Aloe vera on hematological traits, lipid oxidation of carcass and performance in rainbow trout (Oncorhynchus mykiss). Online Journal of Animal and Feed Research 1: 1-5

Faulk C, Benninghoff A D \& Holt G (2007). Ontogeny of the gastrointestinal tract and selected digestive enzymes in cobia Rachycentron canadum (L.). Journal of Fish Biology 70(2): 567-583. https://doi.org/10.1111/j.1095-8649.2007.01330.x

German D P, Horn M H \& Gawlicka A (2004). Digestive enzyme activities in herbivorous and carnivorous prickleback fishes (Teleostei: Stichaeidae): ontogenetic, dietary, and phylogenetic effects. Physiological and Biochemical Zoology 77(5): 789-804. https://doi.org/10.1086/422228

Gobi N, Ramya C, Vaseeharan B, Malaikozhundan B, Vijayakumar S, Murugan K \& Benelli G (2016). Oreochromis mossambicus diet supplementation with Psidium guajava leaf extracts enhance growth, immune, antioxidant response and resistance to Aeromonas hydrophila. Fish \& Shellfish Immunology 58: 572-583. https://doi.org/10.1016/j.fsi.2016.09.062

Heidarieh M, Mirvaghefi A R, Akbari M, Farahmand H, Sheikhzadeh N, Shahbazfar A A \& Behgar M (2012). Effect of dietary Ergosan on growth performance, digestive enzymes, intestinal histology, hematological parameters and body composition of rainbow trout (Oncorhynchus mykiss). Fish Physiology and Biochemistry 38(4): 1169-1174. https://doi.org/10.1007/s10695-012-9602-8

Heidarieh M, Mirvaghefi A R, Sepahi A, Sheikhzadeh N, Shahbazfar A A \& Akbari M (2013). Effects of dietary Aloe vera on growth performance, skin and gastrointestine morphology in rainbow trout (Oncorhynchus mykiss). Turkish Journal of Fisheries and Aquatic Sciences 13(2): 367-373. https://doi.org/10.4194/1303-2712-v13_2_20

Hoseinifar S H, Yousefi S, Van Doan H, Ashouri G, Gioacchini G, Maradonna F \& Carnevali O (2020). Oxidative stress and antioxidant defense in fish: The implications of probiotic, prebiotic, and synbiotics. Reviews in Fisheries Science \& Aquaculture 1-20. https://doi.org/10.1080/23308249.2020.1795616

Jiang H \& Wang X (2012). Time-dependent nanogel aggregation for naked-eye assays of $\alpha$-amylase activity. Analyst 137(11): $2582-2587$. https://doi.org/10.1039/C2AN00038E

Kleijn D \& Steinger T (2002). Contrasting effects of grazing and hay cutting on the spatial and genetic population structure of Veratrum album, an unpalatable, long-lived, clonal plant species. Journal of Ecology 90(2): 360-370. https://doi.org/10.1046/j.1365-2745.2001.00676.x

Mohamed G A, Amhamed I D, Almabrok A A, Barka A B A, Bilen S \& Elbeshti R T (2018). Effect of celery (Apium graveolens) extract on the growth, haematology, immune response and digestive enzyme activity of common carp (Cyprinus carpio). Marine Science and Technology Bulletin 7(2): 51-59. https://doi.org/10.33714/masteb.457721

Moritomo T, Serata K, Teshirogi K, Aikawa H, Inoue Y, Itou T \& Nakanishi T (2003). Flow cytometric analysis of the neutrophil respiratory burst of ayu, Plecoglossus altivelis: comparison with other fresh water fish. Fish \& Shellfish Immunology 15(1): 29-38. https://doi.org/10.1016/s1050-4648(02)00136-5

Ngugi C C, Oyoo-Okoth E, Mugo-Bundi J, Orina P S, Chemoiwa E J \& Aloo P A (2015). Effects of dietary administration of stinging nettle (Urtica dioica) on the growth performance, biochemical, hematological and immunological parameters in juvenile and adult Victoria Labeo (Labeo victorianus) challenged with Aeromonas hydrophila. Fish \& Shellfish Immunology 44(2): 533-541. https://doi.org/10.1016/j.fsi.2015.03.025

Nobahar Z, Gholipour-Kanani H, Kakoolaki S \& Jafaryan H. (2015). Effects of garlic (Allium sativum) and nettle (Urtic adioica) on growth performance and on hematological parameters of beluga (Huso huso). Iranian Journal of Aquatic Animal Health 1(1): 63-69. https://doi.org/10.18869/acadpub.ijaah.1.1.63

Nya E J \& Austin B (2009). Use of garlic, Allium sativum, to control Aeromonas hydrophila infection in rainbow trout, Oncorhynchus mykiss (Walbaum). Journal of Fish Diseases 32(11): 963-970. https://doi.org/10.1111/j.1365-2761.2009.01100.x 
Oskoii S B, Kohyani A T, Parseh A, Salati A P \& Sadeghi E (2012). Effects of dietary administration of Echinacea purpurea on growth indices and biochemical and hematological indices in rainbow trout (Oncorhynchus mykiss) fingerlings. Fish Physiology and Biochemistry 38(4): 1029-1034. https://doi.org/10.1007/s10695-011-9587-8

Öztürk F, Gündüz H \& Sürengil G (2018). Effects of Alginate Based Coatings with Pomegranate Peel Extract on the Microbial Quality of Mackerel Fillets. Journal of Agricultural Sciences 24(4): 445-452. https://doi.org/10.15832/ankutbd.490936

Rätsch C (2016). Enzyklopädie der psychoaktiven Pflanzen: AT Verlag.

Reya T, Morrison S J, Clarke M F \& Weissman I L (2001). Stem cells, cancer, and cancer stem cells. Nature 414(6859): 105-111. https://doi.org/10.1038/35102167

Sahoo P, Kumari J \& Mishra B (2005). Non-specific immune responses in juveniles of Indian major carps. Journal of Applied Ichthyology 21(2): 151-155. https://doi.org/10.1111/j.1439-0426.2004.00606.x

Saurabh S \& Sahoo P (2008). Lysozyme: an important defence molecule of fish innate immune system. Aquaculture Research 39(3): 223-239. https://doi.org/10.1111/j.1365-2109.2007.01883.x

Seeram N, Lee R, Hardy M \& Heber D (2005). Rapid large scale purification of ellagitannins from pomegranate husk, a by-product of the commercial juice industry. Separation and Purification Technology 41(1): 49-55. https://doi.org/10.1016/j.seppur.2004.04.003

Siwicki A K, Anderson D P \& Rumsey G L (1994). Dietary intake of immunostimulants by rainbow trout affects non-specific immunity and protection against furunculosis. Veterinary Immunology and Immunopathology 41(1-2): 125-139. https://doi.org/10.1016/01652427(94)90062-0

Sönmez A Y, Bilen S, Alak G, Hisar O, Yanık T \& Biswas G (2015b). Growth performance and antioxidant enzyme activities in rainbow trout (Oncorhynchus mykiss) juveniles fed diets supplemented with sage, mint and thyme oils. Fish Physiology and Biochemistry 41(1): 165175. https://doi.org/10.1007/s10695-014-0014-9

Sönmez A Y, Bilen S, Albayrak M, Yılmaz S, Biswas G, Hisar O \& Yanık T (2015a). Effects of Dietary Supplementation of Herbal Oils Containing 1,8-cineole, Carvacrol or Pulegone on Growth Performance, Survival, Fatty Acid Composition, and Liver and Kidney Histology of Rainbow Trout (Oncorhynchus mykiss) Fingerlings. Turkish Journal of Fisheries and Aquatic Sciences 15: 813-819. https://doi.org/10.4194/1303-2712-v15_4_04

Sönmez A Y, Özdemir R C, Bilen S \& Yürüten Özdemir K (2018). Cyclopamine Induced Expression of Immune-related Genes in Rainbow trout (Oncorhynchus mykiss) Head Kidney Leukocytes. The Israeli Journal of Aquaculture - Bamidgeh IJA_70.2018.1560-1567

Wilson S R, Strand M F, Krapp A, Rise F, Herstad G, Malterud K E \& Krauss S (2010). Hedgehog antagonists cyclopamine and dihydroveratramine can be mistaken for each other in Veratrum album. Journal of Pharmaceutical and Biomedical Analysis 53(3): 497502. https://doi.org/10.1016/j.jpba.2010.05.024

Worthington V (1993). Catalase. Worthington Enzyme Manual: Enzymes and Related Biochemicals 77-80

(C) 2022 by the author(s). Published by Ankara University, Faculty of Agriculture, Ankara, Turkey. This is an Open Access article distributed under the terms and conditions of the Creative Commons Attribution (CC BY) license (http://creativecommons.org/licenses/by/4.0/), which permits unrestricted use, distribution, and reproduction in any medium, provided the original work is properly cited. 